\title{
The transition from memory retrieval to extinction
}

\author{
MARTÍN CAMMAROTA ${ }^{1}$, DANIELA M. BARROS ${ }^{2}$, MÓNICA R.M. VIANNA ${ }^{1}$, \\ LIA R.M. BEVILAQUA ${ }^{1}$, ADRIANA COITINHO ${ }^{1}$, GERMÁN SZAPIRO ${ }^{3}$, \\ LUCIANA A. IZQUIERDO ${ }^{1}$, JORGE H. MEDINA $^{3}$ and IVÁN IZQUIERDO ${ }^{1}$ \\ ${ }^{1}$ Centro de Memória, ICS, Departamento de Bioquímica, Universidade Federal Do Rio Grande Do Sul \\ Ramiro Barcelos 2600 - Anexo, 90035-003 Porto Alegre, RS, Brasil \\ ${ }^{2}$ Departamento de Ciências Fisiológicas, Fundação Universidade Federal do Rio Grande \\ Av. Itália, Km 8 - 96201-900 Rio Grande, RS, Brasil \\ ${ }^{3}$ Instituto de Biologia Celular y Neurociência "Eduardo De Robertis", Facultad de Medicina \\ Universidad de Buenos Aires, Paraguay 2155, Buenos Aires 1113, Argentina \\ Manuscript received on February 24, 2004; accepted for publication on February 26, 2004; \\ contributed by IVÁN IzQUIERDO*
}

\begin{abstract}
Memory is measured by measuring retrieval. Retrieval is often triggered by the conditioned stimulus (CS); however, as known since Pavlov, presentation of the CS alone generates extinction. One-trial avoidance (IA) is a much used conditioned fear paradigm in which the CS is the safe part of a training apparatus, the unconditioned stimulus (US) is a footshock and the conditioned response is to stay in the safe area. In IA, retrieval is measured without the US, as latency to step-down from the safe area (i.e., a platform). Extinction is installed at the moment of the first unreinforced test session, as clearly shown by the fact that many drugs, including PKA, ERK and protein synthesis inhibitors as well as NMDA receptor antagonists, hinder extinction when infused into the hippocampus or the basolateral amygdala at the moment of the first test session but not later. Some, but not all the molecular systems required for extinction are also activated by retrieval, further endorsing the hypothesis that although retrieval is behaviorally and biochemically necessary for the generation of extinction, this last process constitutes a new learning secondary to the unreinforced expression of the original trace.
\end{abstract}

Key words: memory, retrieval, extinction, reconsolidation, inhibitory avoidance.

\section{INTRODUCTION}

Memory retrieval involves the rapid reactivation of memories that lay dormant. It is triggered by a total or partial reinstatement of the CS, the US, other related stimuli, other related memories and, in humans, often by an act of will. Retrieval has been traditionally considered to depend on the hippocampus (Eldridge et al. 2000, Corcoran and Maren 2001,

* Member of Academia Brasileira de Ciências Correspondence to: Dr. Iván Izquierdo

E-mail: izquier@terra.com.br
Anderson et al. 2004). However, recently it was shown that retrieval of as simple a task as one-trial inhibitory avoidance requires the simultaneous intervention of the hippocampus, the entorhinal, posterior parietal and anterior cingulate cortices, and the basolateral amygdala (Barros et al. 2003), through specific molecular mechanisms in each case.

In the hippocampus and all the neocortical areas examined, normal functioning of the PKA and ERK signaling systems and activation of metabotropic glutamate receptors are necessary for retrieval 
(Barros et al. 2000, 2003, Izquierdo et al. 2001). The metabotropic receptors are needed alongside AMPA receptors in hippocampus and entorhinal cortex, and in addition to NMDA receptors in the parietal and anterior cingulate cortex (Barros et al. 2000). AMPA receptors mediate regular glutamatergic transmission, whereas the activation of NMDA and metabotropic receptors is believed to underlie information-carrying processes (Riedel et al. 2003)

In the amygdala, intact glutamate AMPA receptors, but not NMDA or metabotropic receptors nor PKA or ERK are required for retrieval (Barros et al. 2000, Izquierdo et al. 2001). This suggests that the amygdala plays a modulatory role in retrieval but does not participate in the informational processes that bring up the recall of each particular memory (de Quervain et al. 2000, Roozendaal 2002).

\section{RETRIEVAL MODULATION}

It is common knowledge that retrieval is heavily and decisively influenced by emotions, mood and stress; students who perform poorly at frightening exams in spite of having studied a lot attest to this, as do actors who experience stage fright and teachers who are suddenly impressed by standing in front of a class or who are tired, depressed or burnt-out. When frightened or menaced, all of us readily retrieve defensive postures or gestures of attack, of which we were not aware we knew prior to the menacing situation. We had learned them long ago, they lay dormant in our brains, but they are ready to jump to the front line when necessary.

There are three major sources of retrieval modulation. One comprises the noradrenergic, dopaminergic, serotoninergic and cholinergic systems of the brain that participate both in the perception of, and in the response to, stress, anxiety, fear or aversiveness, as well as in the regulation of mood.

In the hippocampus, entorhinal cortex, posterior parietal cortex and anterior cingulate cortex, $\beta$-noradrenergic, D1-dopaminergic and muscarinic cholinergic receptors facilitate, and serotonin-1A receptors hinder, retrieval; in the amygdala only the $\beta$-noradrenergic system, among brain modulatory systems, influences retrieval (Barros et al. 2001). This multiple modulation of retrieval, particularly in the cortex, probably explains why retrieval is so fragile and so dependent on emotional states and mood. The failure of any of these sets of synapses (say, the blockade of D1 receptors in the entorhinal cortex or of cholinergic receptors in the hippocampus) inhibits retrieval completely. D1-dopaminergic and $\beta$-noradrenergic receptors, through actions at $\mathrm{G}$ proteins, enhance activity of adenylyl cyclase and thus indirectly facilitate PKA activity. Serotonin$1 \mathrm{~A}$ receptors inhibit adenylyl cyclase and would be expected to downregulate PKA activity (Ardenghi et al. 1997). Cholinergic muscarinic receptors, alongside with NMDA glutamate receptors, would be expected to enhance PKC activity (Izquierdo and Medina 1997, Barros et al. 2001).

It is possible that the modulatory influence of these receptors on retrieval is explainable by their effect upon the signaling pathways mentioned, as is the case in consolidation (Ardenghi et al. 1997). What is not known is what are the actual mechanisms of retrieval triggered or gated into action by PKA, PKC or, for that matter, ERK. One possibility may be the phosphorylation of glutamate receptors (Micheau and Riedel 1999), and therefore the momentary enhancement of their activity (Riedel et al. 2003).

The second major mechanism(s) involved in retrieval regulation is that of the hormones. Glucocorticoids acting on the amygdala inhibit retrieval (Roozendaal 2002), which explains the memory "blanks" often seen in stressful situations mentioned above. The stress hormones, adrenaline, vasopressin, $\beta$-endorphin and adrenocorticotropin (ACTH) have long been known to enhance retrieval at low to moderate doses (Barros et al. 2002), but they may hinder retrieval at high doses (de Almeida and Izquierdo 1984). It is interesting that corticosteroids do not share the enhancing effect of ACTH at low doses; indeed, they regularly depress retrieval through an action mediated by reflex pathways in- 
volving inhibition of a $\beta$-noradrenergic mechanism in the basolateral amygdala (Roozendaal 2002). No doubt sex hormones regulate retrieval of sex-oriented behavior, as is attested by the importance of imagery and foreplay in sexual behavior in humans and some mammals. In addition, hormones related to hunger and satiety regulate our retrieval of behavior related to eating.

The third important modulator of retrieval is the influence of other information added to the stimulus complex at the time of retrieval. One of such influences is novelty. Exposure to a novel environment or to a novel set of stimuli 0-180 min prior to a memory retention test enhances retrieval of onetrial avoidance (Izquierdo et al. 2001, 2003) and other tasks (Barros et al. 2003). The effect of novelty depends on activation of hippocampal NMDA receptors, ERK1/2 pathway, and on the phosphorylation of the constitutive transcription factor, CREB (cAMP-dependent response binding element) (Izquierdo et al. 2001). This suggests that it has a component associated to learning about the novel environment; exposure to an environment to which the animals had been exposed before does not influence retrieval of the one-trial avoidance task (Izquierdo et al. 2001, 2002). Additional and often misleading cognitive information may be added at the time of retrieval, such as that furnished by leading questions (Loftus and Palmer 1974). Leading questions, mixtures with other memories and false conclusions may all eventually lead to the substitution of real memories by false ones, a phenomenon quite common in the elderly population (Schacter and Dodson 2001).

\section{LINKS AMONG BRAIN AREAS INVOLVED IN RETRIEVAL}

There are reasons to believe that the main structure involved in retrieval is the hippocampus; mainly that the hippocampus is the foremost and sometimes the only area of the brain whose blood flow increases during retrieval (Eldridge et al. 2000, Anderson et al. 2004). But, as shown above, in the rat at least many other areas of the brain participate in retrieval simultaneously with the hippocampus (Barros et al. 2000, 2001, 2003).

The parietal and cingulate cortex are linked to the hippocampus by afferent and efferent pathways via the entorhinal cortex. The pharmacological experiments mentioned above indicate that certain receptor and enzymatic systems are necessary for retrieval in the hippocampus and in related cortical areas, and are unable to discriminate whether the hippocampus is more important than the other areas. A PKA or ERK inhibitor blocks retrieval completely when given into any of these regions. This does not necessarily mean that all are equally important; imaging studies attest to a predominant role of the hippocampus (Eldridge et al. 2000, Anderson et al. 2004).

\section{THE RETRIEVAL OF SHORT-TERM MEMORY}

Immediately after acquisition, declarative memories are stored by the hippocampus and the entorhinal cortex as two separate, but linked, memory traces: a short-term form of memory (STM), which lasts less than $6 \mathrm{~h}$ (Izquierdo et al. 1998, 2002) and a long-term memory (LTM) that takes about $6 \mathrm{~h}$ to be consolidated into a more or less stable form (Izquierdo and Medina 1997) and which lasts for days, months or years (Izquierdo et al. 1998, 2002, Vianna et al. 2000).

The role of STM is to maintain responsiveness of the animals to the recently learned task while its LTM is being slowly built-up (McGaugh 1966, 2000, Izquierdo et al. 1998, 2002). This no doubt is important for cognition in general; it would be very difficult to understand cognition or behavior in general if animals could only retrieve after several hours from learning. As an example, imagine just any kind of dialogue or serial action in any species without a separate STM system. The separation of STM from LTM and their intrinsic nature were demonstrated by numerous experiments in which diverse pharmacological treatments given into the hippocampus and entorhinal cortex (but not the prefrontal cortex or the amygdala) were found to selectively block 
STM while leaving LTM intact in the same animal and for the same task (Izquierdo et al. 1998, 2000, Vianna et al. 2000).

Retrieval of STM is simpler and requires a relatively small number of molecular processes in the hippocampus (Izquierdo et al. 2001). This is of course intrinsic to the nature and the role of STM in cognition (Izquierdo et al. 2002).

There is no extinction of STM during its duration, 4.5 to $6 \mathrm{~h}$. This is what would be expected from a form of memory that should not fail during the time in which the more complex LTM is being built. The lack of extinction of STM can be explained by the fact that its retrieval is metabolically simpler than that of LTM; simply there are no retrieval-triggered molecular events are there to initiate extinction (see above).

\section{THE REPRESSION OF MEMORIES}

The two major ways to inhibit retrieval are through extinction (Pavlov 1927, Rescorla 2001) and through repression. Extinction is a complex process that will be dealt with in the next section. Current evidence indicates that the two main areas of the brain involved in extinction are the hippocampus and the basolateral amygdala (Myers and Davis 2002, Bahar et al. 2003, Vianna et al. 2001), although in particular cases other areas may also play a role (i.e., the insular cortex, Berman and $\mathrm{Du}-$ dai 2001).

Repression, as described by Freud (Freud 1962), was a mysterious phenomenon whose biological basis remained unexplained until very recently. Anderson et al. (2004) showed that it depends on dorso-lateral prefrontal areas that are activated each time that correct responses are suppressed. These areas project to the hippocampus through the entorhinal cortex. Anderson et al. (2004) showed that when the prefrontal areas are activated by suppressor responses, there is a much reduced activation of the hippocampus than when the correct responses are not suppressed. Therefore, Freudian repression (Freud 1962) correlates with an inhibitory influence of circumscribed areas of the dorso-lateral prefrontal cortex on the hippocampus (Anderson et al. 2004). The molecular correlates of repression have yet to be worked out both in the prefrontal areas and in the hippocampus. This will be difficult since repression is best studied in humans. But it might be important since a modulation of repression should be useful both for psychoanalytic studies and for studies on the repression of fearsome or otherwise unwanted memories.

\section{BIOCHEMICAL CHANGES FOLLOWING RETRIEVAL}

Considering that the hippocampus is apparently the key brain area responsible for retrieval (Eldridge et al. 2000, Corcoran and Maren 2001, Izquierdo et al. 2000), does retrieval involve just the participation of hippocampal PKA, the ERK system, and $\alpha / \beta$ I-PKC at their regular levels, or does it require a particular activation of any of these sys-tems? Retrieval is a very rapid process in which the reactivation of a dormant memory trace develops in seconds; animals have no way of "knowing" that they will be asked to retrieve when taken from the animal room to the apparatus at the time of testing. Somebody who falls unexpectedly into a swimming pool will instantly retrieve all (s)he knows about swimming in fractions of a second. Thus, no particular change in the activity of PKA, ERK or PKC should be expected at the time of retrieval or very shortly thereafter. Should any changes be observed, they might be considered to be changes brought about by retrieval that participate in other processes triggered or brought into play by it. Some such changes have been observed in the rat hippocampus (Szapiro et al. 2000, 2002); while they are obviously linked to and triggered by the act of retrieval, they cannot participate in that act inasmuch as they are registered after retrieval is over. Since the reactivation of a memory that lay dormant in retrieval is instantaneous, one would expect it to depend on the maintenance of the on-going activity of signaling pathways, rather than on their stimulus-induced activation, however rapid this may be. The biochemical changes observed after a re- 
trieval test (Szapiro et al. 2002) will be referred to again and in detail later on, à propos the possible molecular bases of extinction. Stimulus-induced (or retrieval-induced) enzyme activation or CREB phosphorylation, like gene expression and protein synthesis would be expected to underlie processes that are initiated by retrieval, rather than retrieval itself.

As mentioned above, there are no inklings on why the intervention of one or other type of glutamate receptors or of PKA, PKC, CaMKII and the ERKs in retrieval is necessary for retrieval. Perhaps the best educated guess at this time is that those enzymes influence the phosphorylation state of the glutamate receptors (Micheau and Riedel 1999, Riedel et al. 2003) involved in the transmission of the learned information that the brain requires to be retrieved.

\section{EXTINCTION AS THE MAJOR CONSEQUENCE OF RETRIEVAL}

It has been known classically that the presentation of the CS unaccompanied by the US leads to extinction of the learned response(s) (Pavlov 1927). This has been observed both for classically and instrumentally conditioned responses (Konorski 1948, Izquierdo et al. 1965) and is considered to result from a new association, CS-no US, that supersedes that of the original response (CS-US).

The CS-no US association begins to exert its role in the genesis of extinction the first time it is perceived by the animal (Pavlov 1927, Rescorla 2001). In experiments using avoidance instrumental conditioning the new association, CS-no US may take some time and several retention tests to take "hold" (i.e., Izquierdo et al. 1965), because omission of the US in "successful" trials is precisely part of the original training (Konorski 1948). In one-trial inhibitory avoidance experiments, the very first time that animals are exposed to retrieval without the footshock (i.e., the US), extinction becomes installed. This is attested by the fact that, as will be seen, numerous treatments given at the time of the first of a series of retention tests can inhibit retention as measured in succeeding tests.

Some have entertained the possibility that the presentation of the CS alone following a CS-US training may serve not only as a reminder or a primer for the retrieval of that memory, but also as a generator of reconsolidation (Nader 2003). True enough, the CS or other stimuli (the US, a variety of drugs, fragments of the CS) serve as reminders, a fact that stems from the discovery and first descriptions of conditioned reflexes (Pavlov 1927, Konorski 1948). Further, there is no doubt that memories that normally lay dormant are reactivated by the CS or the reminder stimuli, and that at the time of retrieval they become particularly labile: They not only begin to undergo extinction, but also may incorporate additional information, both cognitive (Loftus and Palmer 1974) and neurohumoral (Izquierdo 1989). Memories may change by this to the point of becoming false memories (Schacter and Dodson 2001).

However, the reconsolidation hypothesis rests so far only on the demonstration that anisomycin given to the animal at the time of the first of two retention tests sometimes (Vianna et al. 2001, Nader 2003) but not always (Vianna et al. 2003) hinders retrieval in the $2^{\text {nd }}$ test. Further testing usually reveals that the $2^{\text {nd }}$ test dip, if at all present, is a temporary phenomenon and therefore ascribable to a performance effect of anisomycin: from the $3^{\text {rd }}$ test on, animals that receive anisomycin in the hippocampus on the $1^{\text {st }}$ test show instead decreased extinction (Vianna et al. 2001, 2003).

Whatever its value, were it possible to demonstrate it unequivocally, which has so far been not the case (Vianna et al. 2001), the eventual occurrence of reconsolidation in the $1^{\text {st }}$ of a series of retention tests does not undermine the old and prevalent notion that the regular outcome of unreinforced retrieval is extinction (Myers and Davis 2002, Vianna et al. 2001, 2003). Obviously, in most cases extinction prevails; that is why it is used psychotherapeutically since Freud (1962) for the treatment of disorders caused by learned fear (Myers and Davis 2002, Cammarota et al. 2003). This form of therapy is often called exposure therapy and is very effective 
against phobias (Freud 1962) and in the treatment of the posttraumatic stress disorder (see also Rothbaum and Schwartz 2002).

\section{MOLECULAR BASIS OF EXTINCTION}

There have been several studies indicating that extinction depends on glutamate NMDA receptors, signaling pathways, gene expression and protein synthesis in selected brain areas, just like any other form of new learning (Myers and Davis 2002; see also Quirk and Gehlert 2003). This has been observed in the basolateral amygdala for conditioned startle behavior (Lu et al. 2001, Walker et al. 2002, Myers and Davis 2002), conditioned taste aversion (Bahar et al. 2003) and one-trial inhibitory avoidance, in the hippocampus for one-trial inhibitory avoidance (Vianna et al. 2001, 2003, Szapiro et al. 2003), and in the insular cortex for conditioned taste aversion (Berman and Dudai 2001, Bahar et al. 2003). Studies using selective pharmacological inhibitors have shown that gene expression, protein synthesis and the ERK and PKA pathways in hippocampus and basolateral amygdala are required for extinction of one-trial avoidance longterm memory.

Work by Quirk and his collaborators have suggested a circuit for extinction of fear responses, connecting the ventral medial prefrontal cortex and the amygdala (which is of course connected to the hippocampus by the entorhinal cortex). Milad and Quirk found that stimulation of the medial prefrontal cortex decreases the responsiveness of central amygdala neurons that regularly fire to the CS only when animals are recalling extinction of a fear task learned using that CS (Milad and Quirk 2002). The problem with this finding is that in other experiments, using other tasks, it appears to be the basolateral rather than the central amygdala nucleus that is involved specifically in extinction ( $\mathrm{Lu}$ et al. 2001, Walker et al. 2002, Bahar et al. 2003); but there are both direct and entorhinal-cortex mediated connections between the two regions of the amygdala (Bahar et al. 2003).
In any case, the ventral medial prefrontalamygdala circuit suggested by Quirk and coworkers to be involved in extinction (Quirk and Gehlert 2003) is parallel to the dorso-lateral prefrontalhippocampal circuit proposed by Anderson et al. (2004) for memory repression. Extinction and repression are the two main physiological ways to inhibit unwanted memories, such as are those of fearsome experiences.

The signaling pathways involved in extinction vary in different structures depending on the task. In the amygdala, the ERK pathway is crucial for the extinction of conditioned startle (Lu et al. 2001) but not for that of one-trial avoidance. Extinction of one-trial avoidance requires hippocampal CaMKII in addition to PKA and ERK (Szapiro et al. 2003). None of these signaling pathways appears to play a role in the insular cortex in extinction of conditioned taste aversion (Berman and Dudai 2001); but the key area for extinction of this task may well be the basolateral amygdala rather than the insula (Bahar et al. 2003).

The molecular requirements of extinction mentioned above are different from those of fear conditioning in one respect: they are crucial at the time of the first CS-no US contingency, in the $1^{\text {st }}$ retrieval test. They play a role only at the time of the initiation of extinction and shortly thereafter; 1 or more later they are no longer needed (see Myers and Davis 2002, Vianna et al. 2003). In regular CS-US Pavlovian or instrumental fear conditioning there are two waves of molecular requirements, one immediately after and the second $3 \mathrm{~h}$ after acquisition (Izquierdo and Medina 1997, Igaz et al. 2002). Both waves coincide with increases in PKA activity (Bernabeu et al. 1997) and levels of P-CREB, the latter being a molecular marker of the formation of new memory (Bernabeu et al. 1997, Taubenfeld et al. 1999, Cammarota et al. 2000). In extinction, there is an increase of the activity of two enzymes of the ERK pathway, p42 and p44, and of P-CREB immediately after the $1^{\text {st }}$ retrieval test, i.e., the one in which the CS-no US pairing is first perceived. There is no change of PKA activity and the ERK and P-CREB 
changes do not persist beyond a few minutes and do not reappear at $3 \mathrm{~h}$ from the end of that session (Szapiro et al. 2002).

Certainly these biochemical changes correlate well with the observed effect of protein synthesis or signaling pathway inhibitors on extinction (see above) and are therefore, in all likelihood, representative of the molecular basis of extinction.

It was discussed above and elsewhere (Szapiro et al. 2000, 2002, Vianna et al. 2003) that the molecular changes underlying the beginnings of extinction are in all probability triggered by retrieval. Thus, at least in part, retrieval (if unreinforced) may be viewed as an event that plants the seeds of its own extinction. This of course agrees with the traditional views of Pavlov (1927), Konorski (1948), and more recently Rescorla (2001), Quirk and Gehlert (2003) or us (Barros et al. 2003) on the nature of extinction as a new learning elicited by the perception of a CS-no US connection.

\section{FINAL COMMENT AND CONCLUSIONS}

Memories can only be measured by measuring retrieval. But retrieval, if unreinforced, generates the extinction of memories. The process starts precisely at the time of retrieval, involves new learning and, if retrieval is repeated, extinction progresses more and more, up to a point in which full relearning might be necessary in order to reinstall the original response. Retrieval triggers a number of molecular processes, several of which are involved in the genesis of extinction. Extinction and memory repression are the two main physiological processes that reduce the probability of responding unwanted memories. Both depend on defined brain structures; the medial prefrontal cortex in the case of repression, and the hippocampus and amygdala for extinction. STM is retrieved through much simpler mechanisms in the hippocampus than those that are required for LTM retrieval. STM shows no extinction during the time in which STM remains active (the first 4.5-6 $\mathrm{h}$ after training). Both STM and LTM, as well as their retrieval and extinction are obviously necessary for cognition and for integrated behavior. Extinction can be, and is, used for the treatment of psychiatric conditions based on learned fear: phobias, panic, generalized anxiety and, particularly, the posttraumatic stress disorder.

\section{RESUMO}

A retenção das memórias é avaliada através da sua expressão. A expressão do traço mnemônico é iniciada freqüentemente pelo estímulo condicionado (CS); porém, como definido por Pavlov, a apresentação apenas do CS induz extinção. A esquiva inibitória de apenas uma sessão (IA) é um paradigma de condicionamento ao medo muito utilizado, no qual o CS é a parte segura da caixa de treinamento (plataforma), o estímulo incondicionado (US) é um choque aplicado nas patas do animal quando o mesmo desce da plataforma e a resposta condicionada é permanecer na área segura. Na IA, a expressão da memória é medida na ausência do US, sendo definida como a latência para descer da área segura. A extinção é instalada no momento da primeira sessão de teste, tal como fica claramente demonstrado pelo fato de que várias drogas, entre elas inibidores de síntese protéica, de PKA e de ERK e antagonistas dos receptores NMDA, impedem a extinção quando administrados no hipocampo ou na amígdala basolateral no momento da primeira sessão de teste, mas não mais tardiamente. Alguns, mas não todos os sistemas moleculares requeridos para a extinção, também são ativados pela expressão das memórias, fortalecendo a hipótese de que mesmo que a expressão seja comportamental e bioquimicamente necessária para a ocorrência da extinção, este último processo constitui um novo aprendizado, secundário a expressão do traço original.

Palavras-chave: memória, expressão, extinção, reconsolidação, esquiva inibitória.

\section{REFERENCES}

Anderson MC, Ochsner KN, Kuhl B, CoOper J, Robertson E, Gabrieli SW, Clover GH and GABRIELI JDE. 2004. Neural systems underlying the suppression of unwanted memories. Science 303: 232-235.

Ardenghi P, Barros D, Izquierdo LA, Bevilaqua L, 
Schroder N, Quevedo J, Rodrigues C, Madruga M, Medina JH and IzQuierdo I. 1997. Late and prolonged post-training memory modulation in entorhinal and parietal cortex by drugs acting on the cAMP/protein kinase A signalling pathway Behav Pharmacol 8: 745-751.

Bahar A, Samuel A, Hazvi S and Dudai Y. 2003. The amygdalar circuit that acquires taste aversion memory differs from the circuit that extinguishes it. Eur J Neurosci 17: 1527-1530.

Barros DM, Izquierdo LA, Mello e Souza T, Ardenghi PG, Pereira P, Medina JH and IzQuierDO I. 2000. Molecular signalling pathways in the cerebral cortex are required for retrieval of onetrial avoidance learning in rats. Behav Brain Res 114: 183-192.

Barros DM, Mello e Souza T, de David T, Choi H, Aguzzoli A, Madche C, Ardenghi P, Medina JH AND IzQUIERDO I. 2001. Simultaneous modulation of retrieval by dopaminergic $\mathrm{D}(1)$, beta-noradrenergic, serotonergic-1A and cholinergic muscarinic receptors in cortical structures of the rat. Behav Brain Res 124: 1-7.

Barros DM, IzQuierdo LA, MEdina JH ANd IZquierDO I. 2002. Bupropion and sertraline enhance retrieval of recent and remote long-term memory in rats. Behav Pharmacol 13: 215-220.

Barros DM, IzQuierdo LA, Medina JH AND IzQUierDO I. 2003. Pharmacological findings contribute to the understanding of the main physiological mechanisms of memory retrieval. Curr Drug Target CNS Neurol Disord 2: 81-94

Berman DE ANd Dudai Y. 2001. Memory extinction, learning anew, and learning the new: dissociations in the molecular machinery of learning in cortex. Science 291: 2417-2419.

Bernabeu R, Bevilaqua L, Ardenghi P, Bromberg E, Schmitz P, Bianchin M, IzQuierdo I AND Medina JH. 1997. Involvement of hippocampal cAMP/cAMP-dependent protein kinase signaling pathways in a late memory consolidation phase of aversively motivated learning in rats. Proc Natl Acad Sci 94 : 7041-7046.

Cammarota $\mathrm{M}$, Bevilaqua LR, Ardenghi $\mathrm{P}$, Paratcha G, Levi de Stein M, Izquierdo I and Medina JH. 2000. Learning-associated activation of nuclear MAPK, CREB and Elk-1, along with Fos production, in the rat hippocampus after a one-trial avoidance learning: abolition by NMDA receptor blockade. Mol Brain Res 76: 36-46.

Cammarota M, Bevilaqua LR, Kerr D, Medina JH AND IZQUIERDO I. 2003. Inhibition of mRNA and protein synthesis in the CA1 region of the dorsal hippocampus blocks reinstallment of an extinguished conditioned fear response. J Neurosci 23: 737-741.

Corcoran KA And Maren S. 2001. Hippocampal inactivation disrupts contextual retrieval of fear memory after extinction. J Neurosci 21: 1720-1726.

DE Almeida MA And IzQuierdo I. 1984. Effect of the intraperitoneal and intracerebroventricular administration of ACTH, epinephrine, or beta-endorphin on retrieval of an inhibitory avoidance task in rats. Behav Neural Biol 40: 119-122.

de Quervain DJ, Roozendaal B, Nitsch RM, McGaugh JL AND Hock C. 2000. Acute cortisone administration impairs retrieval of long-term declarative memory in humans. Nat Neurosci 3: 313-314.

EldRidge LL, KNOWlton BJ, Furmanski CS, Bookheimer SY AND ENGel SA. 2000. Remembering episodes: a selective role for the hippocampus during retrieval. Nat Neurosci 3: 1149-1152.

Freud S. 1962. The Standard Edition of the Complete Psychological Works of Sigmund Freud, Vol. 3, p. 74; vol 10, p.5, vol. 20, p. 87. (London, Hogarth Press).

Igaz LM, Vianna MR, Medina JH and IzQuierdo I. 2002. Two time periods of hippocampal mRNA synthesis are required for memory consolidation of fearmotivated learning. J Neurosci 22: 6781-6789.

IZQUIERDO I. 1989. Different forms of posttraining memory processing. Behav Neural Biol 51: 171-202.

IzQuierdo I ANd Medina JH. 1997. Memory formation: the sequence of biochemical events in the hippocampus and its connection to activity in other brain structures. Neurobiol Learn Mem 68: 285-316.

IzQuiERdo I, Wyrwicka W, Sierra G and SEgundo JP. 1965. Establishment of a trace reflex during natural sleep of cats. Actual Neurophysiol (Paris) 6: 277296.

IzQuierdo I, Barros DM, Mello e Souza T, DE SouzA MM, IzQuiERdo LA ANd MEdinA JH. 1998. Mechanisms for memory types differ. Nature 393: 635-636. 
IzQuierdo LA, BArros DM, Ardenghi PG, Pereira P, Rodrigues C, Choi H, Medina JH ANd IzQuierdo I. 2000. Different hippocampal molecular requirements for short- and long-term retrieval of one-trial avoidance learning. Behav Brain Res. 111: 93-98.

Izquierdo LA, Viola H, Barros DM, Alonso M, Vianna MR, Furman M, Levi de Stein M, Szapiro G, Rodrigues C, Choi H, Medina JH AND IZQUIERDO I. 2001. Novelty enhances retrieval: molecular mechanisms involved in rat hippocampus. Eur J Neurosci 13: 1464-1467.

IzQuierdo LA, Barros DM, Vianna MR, Coitinho A, Dedavid e Silva T, Choi H, Moletta B, Medina JH AND IZQUIERDo I. 2002. Molecular pharmacological dissection of short- and long-term memory. Cell Mol Neurobiol. 22: 269-287.

IzQuierdo LA, Barros DM, MEdina JH AND IZQUIERDO I. 2003. Exposure to novelty enhances retrieval of very remote memory in rats. Neurobiol Learn Mem 79: 51-56.

Konorski J. 1948. Conditioned reflexes and Neuron Organisation. (London, London University Press).

Loftus EF AND PALMER JC. 1974. Reconstruction of automobile destruction: An example of interaction between language and memory. J. Verbal Learn. \& Verbal Behav 13: 585-589.

Lu KT, Walker DL and Davis M. 2001. Mitogenactivated protein kinase cascade in the basolateral nucleus of amygdala is involved in extinction of fear-potentiated startle. J Neurosci 21: RC162.

McGaugh JL. 1966. Time-dependent processes in memory storage. Science 153: 1351-1358.

McGaugh JL. 2000. Memory: a century of consolidation. Science 287: 248-251.

Micheau J And Riedel G. 1999. Protein kinases: which one is the memory molecule? Cell Mol Life Sci. 55: 534-548.

Milad MR AND QuiRK GJ. 2002. Neurons in medial prefrontal cortex signal memory for fear extinction. Nature 420: 70-74.

Myers KM And Davis M. 2002. Behavioral and neural analysis of extinction. Neuron 36: 567-584.

NADER K. 2003. Memory traces unbound Trends Neurosci 26: $65-72$.

Pavlov IP. 1927. Conditioned Reflexes (Oxford, Oxford University Press).
Quirk GJ AND GeHLerT DR. 2003. Inhibition of the amygdala: key to pathological states? Ann NY Acad Sci 985: 263-272.

ResCORLA RA. 2001. Retraining of extinguished Pavlovian stimuli. J Exp Psychol Anim Behav Process 27: 115-124.

Riedel G, Platt B and Micheau J. 2003. Glutamate receptor function in learning and memory. Behav Brain Res 140: 1-47.

RoozendaAl B. 2002. Stress and memory: opposing effects of glucocorticoids on memory consolidation and memory retrieval. Neurobiol Learn Mem 78: 578-595.

Rothbaum BO and Schwartz AC. 2002. Exposure therapy for posttraumatic stress disorder. Am J Psychother 56: 59-75.

Schacter DL AND Dodson CS. 2001. Misattribution, false recognition and the sins of memory. Philos Trans R Soc Lond B Biol Sci 356: 1385-1393.

Szapiro G, Izquierdo LA, Alonso M, Barros D, Paratcha G, Ardenghi P, Pereira P, Medina JH AND IzQUIERDO I. 2000. Participation of hippocampal metabotropic glutamate receptors, protein kinase A and mitogen-activated protein kinases in memory retrieval. Neuroscience 99: 1-5.

Szapiro G, Galante JM, Barros DM, Levi de Stein M, Vianna MR, IZquierdo LA, IZQUiERdo I AND Medina JH. 2002. Molecular mechanisms of memory retrieval. Neurochem Res 27: 1491-1498.

Szapiro G, Vianna MR, McGaugh JL, Medina JH AND IzQUIERDO I. 2003. The role of NMDA glutamate receptors, PKA, MAPK, and CAMKII in the hippocampus in extinction of conditioned fear. Hippocampus 13: 53-58.

Taubenfeld SM, Wiig KA, Bear MF and Alberini CM. 1999. A molecular correlate of memory and amnesia in the hippocampus. Nat Neurosci 2: 309310.

Vianna MR, Barros DM, Silva T, Choi H, Madche C, Rodrigues C, Medina JH AND IzQuierdo I. 2000. Pharmacological demonstration of the differential involvement of protein kinase $\mathrm{C}$ isoforms in shortand long-term memory formation and retrieval in rats, Psychopharmacology 150: 77-84.

Vianna MR, Szapiro G, McGaugh JL, Medina JH AND IzQUIERDo I. 2001. Retrieval of memory for 
fear-motivated training initiates extinction requiring protein synthesis in the rat hippocampus. Proc Natl Acad Sci U S A. 98: 12251-12254.

Vianna MR, Igaz LM, CoITInho AS, Medina JH AND IZQUIERDO I. 2003. Memory extinction requires gene expression in rat hippocampus. Neurobiol Learn Mem 79: 199-203.
Walker DL, Ressler KJ, Lu KT AND DAVIS M. 2002. Facilitation of conditioned fear extinction by systemic administration or intra-amygdala infusions of D-cycloserine as assessed with fear-potentiated startle in rats. J Neurosci 22: 2343-2351. 